geneous system, possessing an interface; it shows that this interface is, in fact, very much too large to be satisfied by the amount of oxygen which is actually taken up at saturation, and that therefore the oxygen must be held by some other means than adsorption.

The University, Sheffield,

N. K: Adam. May 24.

\section{Relation between Hæmoglobin-Content and Surface of Red Blood-Cells.}

Bürker (Archiv für die gesammte Physiologie, Cxcv., I922, p. 5I6) has demonstrated that the relation between the hæmoglobin-content and the surface of a single red blood-cell is constant, whatever may be the divergencies in size and hæmoglobincontent of the blood-cells of different animals.

Taking as examples the rabbit, the chromocytes of which are of medium size, and the goat, which has very small red blood-cells, he gives the following numbers :

\begin{tabular}{|c|c|c|c|c|c|c|}
\hline & & 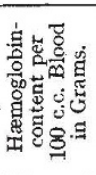 & 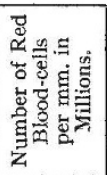 & 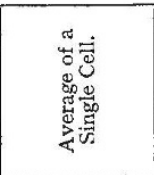 & 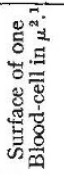 & 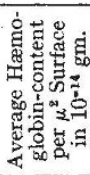 \\
\hline Rabbit & - & 11.9 & 5.86 & $20 \times 10^{-12} \mathrm{gm}$ & 68.4 & 27 \\
\hline Goat & . & $10 \cdot 9$ & $13 \cdot 94$ & $8 \times 10^{-12} \mathrm{gm}$. & $25 \cdot 1$ & 29 \\
\hline
\end{tabular}

1 These numbers are to be multiplied by 1.09 ; vide NATURE, January 6 , 1923.

Now, as is already evident from the numbers given by Abderhalden (" Lehrbuch der physiologischen Chemie"), the relation between the hæmoglobincontent of a blood-cell and its volume is also constant. In the following experiment the volume of the red blood-cells was determined by centrifugation of blood after addition of a trace of sodium fluorate.

\begin{tabular}{|c|c|c|c|c|c|c|}
\hline & 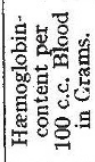 & 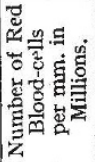 & 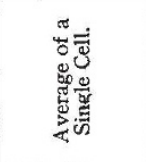 & 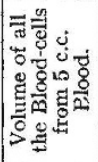 & 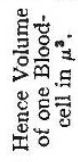 & 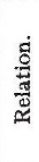 \\
\hline Rabbit . & $10 \cdot 6$ & $5 \cdot 7$ & $19 \times 10^{-12} \mathrm{gm}$. & 1.7 с.с. & 60 & 32 \\
\hline Goat . . & $9 \cdot 6$ & $16 \cdot 3$ & $6 \times 10^{-12} \mathrm{gm}$ & 1.5 c.c. & $18 \cdot 4$ & 31 \\
\hline
\end{tabular}

The constant is the same in both cases. How are these two results to be reconciled?

One hypothesis is that the chromocytes of the goat have not the same shape as those of the rabbit. This hypothesis, however, does not seem to be satisfactory, because microscopic examination of the red blood-cells from the rabbit and the goat does not show an important difference in form.

A second hypothesis is that the method of determining the volume of the red blood-cells by centrifugation of the blood is not trustworthy.

The difficulty may be solved if, for example, the larger cells lost more water by the centrifugal force than the smaller ones; but this does not seem very probable either.

I am specially interested in the solution of this problem, because I am studying the question as to whether the hæmoglobin is distributed about the surface of the red blood-cell in such a way that all the iron is in the position that enables it to act as a catalyser. If we calculate how much iron can be placed at the surface of one human red blood-cell, it appears that this iron can form exactly one monomolecular laver, provided that one atom of iron occupies a surface of $8 \times 10^{-16} \mathrm{~cm}^{2}$. If, however, all the hæmoglobin should be placed at the surface in one monomolecular layer, this surface would have to be a hundred times greater. It seems probable that the surface that governs the law of Bürker must be the surface of all the "micelles" of the hæmoglobinsolution.

First of all, however, it ought to be definitely settled whether Bürker is right, when speaking of a " Hämoglobinverteilungsgesetz."

Leyden, May 7.

\section{E. Gorter.}

\section{A Lost Collection of Indian Sketches.}

In the Geographical Journal for March 1922, it is stated (p. 2Ig) that the Indian sketches made by me could not be found. As these are numerous, quite I6o, made between 1852 and 1858 , some details regarding them, their value as sketches, where and how they were made, may be of interest, and may possibly assist the authorities at Scotland Yard to trace them; even the discovery of one sketch might do so. It will also show fellows of the Royal Geographical Society and others why I have so persistently directed attention to the loss.

The sketches are not a traveller's collection of the ordinary kind; they were made to illustrate the country I was in, and the work on which I was employed. I cannot take a better example than the very first, made after landing in Burma. It was a water-colour sketch of the Lake at Rangoon, from the stockade which then surrounded the Pagoda hill, in its pristine state, now known as the Royal Lakes in Dalhousie Park, its artificial state. This sketch also showed the Rangoon River and hill on which stands the Syriam Pagoda, and how greatly the delta of the Irravady differs from that of the Ganges.

The first sketches go back to I852, the year I obtained my commission and sailed for India, round the Cape, in a small troopship of 590 tons. Landing at Calcutta after a five months' voyage, and finally going on to Burma, where I passed my nineteenth birthday, all my spare time in that country was given up to making a geological map. Burma was then practically unknown, and on being appointed A.D.C. to General T. Godwin, on tours of inspection I saw much of the country.

This work compared well with the Geological map of Pegu as surveyed some years after by Messrs. W. Theobald, W. T. Blanford, and Feddon, only they were able to put an age to the formations seen; beyond knowing that the limestone of Akouk-thoung was very much the oldest, I could not. It was good practice, and many years after when I was-surveying Manipur the knowledge gained was of immense value.

I must explain why when so young an officer I was able to do this. From an early age I had had most unusual opportunities to learn: my father was a geologist, always at work, always collecting, geological friends such as Edward Forbes always in the house. After learning surveying at Sandhurst I was able to help him to make plans near home to illustrate a paper he was writing - "On the Gravel Beds of the Valley of the Wey," Q.J. Geolog. Soc.; vol. vii., 1857 .

I helped to make the plan " On the Valley of the English Channel" (Q.J. Geolog. Soc., February I850, vol. vi.), and learnt a great deal from seeing so much of the plans which finally illustrated the paper 